Fadli Akbar Lubis', Mohamad Harisudin², Rhina Uchyani

Fajarningsih $^{2}$

'Program Studi Agribisnis, Pascasarjana Universitas Sebelas Maret,

Surakarta, Indonesia

${ }^{2}$ Fakultas Pertanian, Universitas Sebelas Maret, Surakarta, Indonesia

*) Email korespondensi: fadliakbar211@gmail.com
AGRARIS: Journal of Agribusiness and Rural Development Research

Vol. 5 No. 2 Juli-Desember 2019

\section{Strategi Pengembangan Agribisnis Cabai Merah di Kabupaten Sleman dengan Metode Analytical Hierarchy Process}

\section{Development Strategy of Red Chili Agribusiness in Sleman Regency using Analytical Hierarchy Process Method}

DOI: http://dx.doi.org/10.18196/agr.5281

\begin{abstract}
This study aims to formulate a strategy for developing red chili agribusiness that can be applied in Sleman Regency. The study was conducted in Kalasan District since it has the highest red chili production in Sleman Regency. The method used in this research was Analytical Hierarchy Process (AHP). Based on the results of the study there were 5 aspects of strength, 5 aspects of weakness, 5 aspects of opportunity, and 5 aspects of threats. All internal and external aspects form the basis for making alternative strategies. The position of grand strategy matrix is quadrant 1. There were 5 alternative strategies that are generated and included in the AHP hierarchy structure. Of the 5 alternative strategies, the 05 strategy was chosen with a priority weight value of 0.357, namely the strategy with the development of a chili auction market using digital technology.
\end{abstract}

Keywords: Red Chili Agribusiness, AHP, Development Strategy

\section{NTISARI}

Penelitian ini bertujuan untuk merumuskan strategi pengembangan agribisnis cabai merah yang dapat diterapkan di Kabupaten Sleman. Penelitian dilaksanakan di Kecamatan Kalasan karena memiliki produksi cabai merah tertinggi di Kabupaten Sleman. Metode yang digunakan dalam penelitian ini adalah Analytical Hierarchy Process (AHP). Berdasarkan hasil penelitian terdapat 5 aspek kekuatan, 5 aspek kelemahan, 5 aspek peluang, dan 5 aspek ancaman. Seluruh aspek internal dan eksternal menjadi dasar dalam membuat alternatif strategi. Posisi matrik grand strategy terletak pada kuadran I. Terdapat 5 alternatif strategi yang dihasilkan dan dimasukan ke dalam struktur hirarki AHP. Dari 5 alternatif strategi, yang terpilih adalah strategi 05 dengan nilai bobot prioritas 0.357, yaitu pengembangan pasar lelang cabai dengan teknologi digital.

Kata kunci : Agribisnis cabai merah, AHP, Strategi pengembangan

\section{PENDAHULUAN}

Berdasarkan Peraturan Menteri Pertanian Republik Indonesia No. 06/Permentan/OT.140/2/2015 Tahun 2015, pengembangan agribisnis didasarkan pada aspek penyediaan sarana produksi, aspek produksi, aspek pemasaran dan pengolahan, serta aspek kelembagaan pendukung (Dirjen Prasarana dan Sarana Pertanian, 2015). Dapat diartikan bahwa sistem agribisnis terbentuk dari subsistem yang tergabung dalam satu rangkaian. Agribisnis mampu mengakomodasi tuntutan agar perekonomian nasional terus bertumbuh dan sekaligus memenuhi prinsip kerakyatan, keberlanjutan dan pemerataan, baik antar individu maupun antar daerah. Atas dasar pemikiran tersebut maka pembangunan sistem agribisnis dipandang sebagai bentuk pendekatan yang paling tepat bagi pembangunan ekonomi nasional (Saragih, 2001). Agribisnis cabai merah memiliki prospek yang bagus jika dikembangkan dengan baik, karena dalam kehidupan sehari-hari 
cabai merah memegang peranan yang penting, terutama bagi kebutuhan rumah tangga dan juga berperan dalam memenuhi gizi masyarakat, selain itu cabai merah jika dibudidayakan dengan tujuan untuk nilai bisnis tentunya dapat menembus pasaran dengan mudah.

Salah satu daerah di Indonesia yang fokus dalam mengembangkan agribisnis cabai merah adalah Kabupaten Sleman di Provinsi Daerah Istimewa Yogyakarta. Sektor pertanian di Kabupaten Sleman merupakan salah satu unggulan bagi perekonomian daerahnya. Berdasarkan data BPS (2018) pada tahun 2017 jumlah produksi meningkat sebesar 17.042 kuintal dari tahun 2016.

\begin{tabular}{|c|c|c|c|}
\hline \multirow[b]{2}{*}{ Kecamatan } & \multicolumn{3}{|c|}{ Cabai merah } \\
\hline & $\begin{array}{l}\text { Luas Panen } \\
\text { (Ha) }\end{array}$ & $\begin{array}{l}\text { Produksi } \\
\text { (Kwt) }\end{array}$ & $\begin{array}{l}\text { Rata-rota Produks } \\
\text { (Kw/Ha) }\end{array}$ \\
\hline 1. Moyudan & 2 & 75 & 37,50 \\
\hline 2. Minggir & 7 & 180 & 25,71 \\
\hline 3. Seyegan & 21 & 627 & 29,86 \\
\hline 4. Godean & 65 & 1.764 & 27,14 \\
\hline 5. Gamping & 30 & 866 & 28,87 \\
\hline 6. Mlati & 60 & 1.582 & 26,36 \\
\hline 7. Depok & 34 & 611 & 17,97 \\
\hline 8. Berbah & 18 & 291 & 16,17 \\
\hline 9. Prambanan & 175 & 2.394 & 13,68 \\
\hline 10. Kalasan & 528 & 11.257 & 21,32 \\
\hline 11. Ngemplak & 263 & 6.148 & 23,38 \\
\hline 12. Ngaglik & 323 & 7.976 & 24,70 \\
\hline 13. Sleman & 150 & 3.608 & 24,05 \\
\hline 14. Tempel & 98 & 2.019 & 20,60 \\
\hline 15. Turi & 265 & 6.195 & 23,38 \\
\hline 16. Pakem & 580 & 11.144 & 19,21 \\
\hline 17. Cangkringan & 211 & 3.930 & 18,63 \\
\hline Jumlah & 2.827 & 60.668 & 21,46 \\
\hline 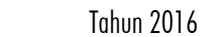 & 703 & 43.626 & 62,06 \\
\hline
\end{tabular}

Sumber : BPS (2018)

Usaha pengembangan agribisnis cabai merah dapat dijadikan sebagai sumber pendapatan masyarakat di Kabupaten Sleman. Adanya lahan yang tersedia dan juga didukung oleh iklim dan sumber air yang cukup maka para petani dapat mengembangkan potensi untuk menanam cabai dengan baik sehingga dapat meningkatkan sumber pendapatan keluarganya. Agribisnis cabai merah menguntungkan baik secara privat maupun sosial dan tidak ada masyarakat yang dirugikan akibat kegiatan agribisnis komoditas tersebut. Dengan demikian agribisnis cabai merah dapat dikembangkan lebih lanjut Input nontradeable usahatani cabai merah telah digunakan secara efisien dan memberikan nilai tambah bagi petani (Antriyandarti \& Ani, 2015).

Di Kabupaten Sleman sektor pertanian adalah salah satu sektor yang banyak dijadikan sebagai sumber untuk memperoleh pendapatan bagi masyarakat, namun dalam hal ini sebagian besar petani hanya berkontribusi di bidang usaha tani tingkat produksi (on-farm) dengan nilai tambah atau keuntungan yang relatif kecil. Petani di Kabupaten Sleman saat ini hanya menjual produknya dalam bentuk cabai segar. Sementara subsistem pengolahan dan pemasaran (off-farm) cenderung tidak ditangani oleh mereka sebagai petani tetapi oleh pedagang atau pebisnis lainnya. Kendala lainnya yang dihadapi oleh petani yaitu serangan penyakit tanaman di lahannya, sehingga menimbulkan kerugian yang besar saat panen. Petani cabai di Kabupaten Sleman mengeluhkan tanamannya yang diserang penyakit dan mengakibatkan daun-daun tanaman cabai menguning. Kondisi ini semakin parah karena masih banyak petani yang tidak mengetahui cara penanggulanan yang baik untuk mengatasi penyakit tersebut. Pada sisi lainnya sering terjadi fluktuasi harga cabai yang membuat harga jual dari petani tidak stabil sehingga menjadi pemicu kerugian bagi mereka. Penelitian ini bertujuan untuk merumuskan serta menentukan alternatif strategi yang dapat diterapkan untuk mengembangkan agribisnis cabai merah di Kabupaten Sleman.

\section{METODE PENELITIAN}

Penelitian dilaksanakan di Kabupaten Sleman sejak bulan Desember 2018 sampai dengan bulan Januari 2019 dengan menggunakan metode deskriptif analitik, yaitu metode yang memusatkan diri pada pemecahan -pemecahan masalah yang ada pada masa sekarang dan pada masalah -masalah yang aktual. Penelitian deskriptif ini untuk membuat deskripsi, 
gambaran, atau lukisan secara sistematis, faktual dan akurat mengenai fakta-fakta, sifat-sifat serta hubungan antarfenomena yang diselidiki (Nazir, 2009). Data yang digunakan adalah data primer dan data sekunder. Pengambilan data dilakukan dengan wawancara langsung dan observasi di kecamatan yang memiliki hasil produksi tertinggi, yaitu Kecamatan Kalasan dengan hasil produksi cabai merah 11.257 kuintal pada tahun 2017.

Responden dalam penelitian ini adalah informan kunci (key informan) yang merupakan subjek yang telah cukup lama dan intensif menyatu dengan kegiatan yang memiliki informasi serta masih terlibat secara penuh pada kegiatan yang menjadi perhatian peneliti. Informan adalah orang yang dimanfaatkan untuk memberikan informasi tentang situasi dan kondisi latar penelitian (Moleong, 2007). Pemilihan informan sebagai sumber data dalam penelitian ini berdasarkan pada asas subyek yang menguasai permasalahan, memiliki data, dan bersedia memberikan informasi lengkap dan akurat yang ditentukan dengan teknik snowball sampling. Karakteristik responden dalam analisis internal dan analisis eksternal adalah :

\section{TABEL 2. KARAKTERISTIK RESPONDEN ANALISIS INTERNAL DAN EKSTERNAL}

\begin{tabular}{|c|c|c|c|c|c|}
\hline No & $\begin{array}{c}\text { Jabatan/ } \\
\text { Pekerjaan }\end{array}$ & $\begin{array}{c}\text { Instansi/ } \\
\text { Lembaga } \\
\end{array}$ & $\begin{array}{c}\text { Jenis } \\
\text { Kelamin }\end{array}$ & Umur & Pendidikan \\
\hline & $\begin{array}{l}\text { Kepala Bidang } \\
\text { Hortikultura dan } \\
\text { Perkebunan }\end{array}$ & $\begin{array}{l}\text { Dinas Pertanian, Pangan dan } \\
\text { Perikanan Kab. Sleman }\end{array}$ & Laki-laki & 57 & S2 \\
\hline 2 & $\begin{array}{l}\text { Kepala Seksi Bina } \\
\text { Produksi Hortikultura }\end{array}$ & $\begin{array}{l}\text { Dinas Pertanian, Pangan dan } \\
\text { Perikanan Kab. Sleman }\end{array}$ & Laki-laki & 47 & S2 \\
\hline 3 & $\begin{array}{l}\text { Pengawas Mutu Hasil } \\
\text { Pertanian Hortikultura }\end{array}$ & $\begin{array}{l}\text { Dinas Pertanian, Pangan dan } \\
\text { Perikanan Kab. Sleman }\end{array}$ & Laki-laki & 44 & S1 \\
\hline 4 & $\begin{array}{l}\text { Kepala Seksi } \\
\text { Pengawasan dan } \\
\text { Pengendalian Industri }\end{array}$ & $\begin{array}{l}\text { Dinas Perindustrian dan } \\
\text { Perdagangan Kab. Sleman }\end{array}$ & Laki-laki & 45 & Sl \\
\hline 5 & Petani & Ketua Gapoktan Kalasan & Laki-laki & 42 & SMA \\
\hline 6 & Petani & $\begin{array}{l}\text { Ketua Sayuran } \\
\text { Kab. Sleman }\end{array}$ & Laki-laki & 47 & SMA \\
\hline & $\begin{array}{l}\text { Penyedia Sarana } \\
\text { Produksi }\end{array}$ & CV Enggal Tani & Laki-laki & 47 & SMA \\
\hline 8 & $\begin{array}{l}\text { Penyedia Sarana } \\
\text { Produksi }\end{array}$ & CV Agro Hit & Laki-laki & 45 & SMA \\
\hline 9 & Pedagang Besar & - & Laki-laki & 48 & SMA \\
\hline & Pedagang Besar & - & Laki-laki & 47 & SMA \\
\hline & Pasar Lelang & Pasar lelang cabai Kab. Sleman & Laki-laki & 45 & SMA \\
\hline
\end{tabular}

Pada penerapan metode AHP yang diutamakan adalah kualitas dari responden, dan tidak tergantung pada kuantitasnya (Saaty, 1993). Oleh karena itu, penilaian AHP memerlukan pakar sebagai responden dalam pengambilan keputusan. Pemilihan responden untuk menentukan prioritas strategi pengembangan agribisnis cabai merah dengan metode AHP dilakukan secara purposive (sengaja). Kriteria yang digunakan sebagai pertimbangan (judgement) dalam pemilihan responden untuk metode AHP menggunakan kriteria pakar.

\section{TABEL 3. KARAKTERISTIK RESPONDEN DALAM AHP}

\begin{tabular}{|c|c|c|c|c|c|}
\hline No & Jabatan & Instansi & $\begin{array}{l}\text { Jenis } \\
\text { Kelamin }\end{array}$ & Umur & Pendidikan \\
\hline & $\begin{array}{l}\text { Kepala Bidang } \\
\text { Hortikultura dan } \\
\text { Perkebunan }\end{array}$ & $\begin{array}{l}\text { Dinas Pertanian, Pangan dan } \\
\text { Perikanan Kab. Sleman }\end{array}$ & Laki-laki & 57 & S2 \\
\hline 2 & $\begin{array}{l}\text { Kepala Seksi Bina } \\
\text { Produksi Hortikultura }\end{array}$ & $\begin{array}{l}\text { Dinas Pertanian, Pangan dan } \\
\text { Perikanan Kab. Sleman }\end{array}$ & Laki-laki & 47 & S2 \\
\hline 3 & $\begin{array}{l}\text { Pengawas Mutu Hasil } \\
\text { Pertanian Hortikultura }\end{array}$ & $\begin{array}{l}\text { Dinas Pertanian, Pangan dan } \\
\text { Perikanan Kab. Sleman }\end{array}$ & Laki-laki & 44 & SI \\
\hline
\end{tabular}
Sumber : Data Primer

Identifikasi terhadap faktor internal dan eksternal sebagai masukan dasar untuk merumuskan strategi. Tahap ini dilakukan untuk mengetahui kekuatan, kelemahan, peluang dan ancaman untuk membuat matrik EFE (External Factor Evaluation) dan IFE (Internal Factor Evaluation) (David, 2011). Setelah faktor-faktor internal dan eksternal diketahui, selanjutnya dinilai atau diberi bobot dengan menggunakan pengukuran skala ordinal oleh responden yang dianggap sebagai pakar, yaitu 2 responden dari petani yang memiliki pengalaman lebih dari 10 tahun, Kepala Seksi Bina Produksi Hortikultura, Pengawas Mutu Hasil Pertanian Hortikultura, dan untuk pemberian rating dilakukan oleh Kepala Bidang Hortikultura dan Perkebunan. Skala ordinal adalah skala pengukuran yang tidak hanya menyatakan kategori, tetapi juga menyatakan peringkat construct yang diukur (Sugiyono, 2014). Setelah hasil dari analisis matrik IFE dan EFE diketahui, dilanjutkan pada tahap matching stage dengan analisis grand strategy. Hasil analisis tersebut dijadikan acuan dalam memperoleh alternatifalternatif yang disusun dalam kerangka hirarki. Alternatif strategi yang telah ditentukan, dinilai oleh pakar dengan menggunakan skala 1 sampai 9 dengan 
membuat matrik perbandingan berpasangan (pairwise comparisons). Perbandingan dilakukan dengan cara judgement dari pakar. Selanjutnya mendefenisikan nilai perbandingan berpasangan untuk mengetahui tingkat konsistensinya. Rasio konsistensi adalah kurang dari atau sama dengan 10\%. Dalam menentukan prioritas strategi pengembangan agribisnis cabai merah di Kabupaten Sleman dipilih alternatif strategi yang memiliki nilai tertinggi.

AHP merupakan suatu model pendukung keputusan yang dikembangkan oleh Thomas L. Saaty. Model pendukung keputusan ini akan menguraikan masalah multi faktor atau multi kriteria yang kompleks menjadi suatu hirarki. Hirarki didefenisikan sebagai suatu representasi dari sebuah permasalahan yang kompleks dalam suatu struktur multi level dimana level pertama adalah tujuan, yang diikuti level faktor, kriteria, sub kriteria, dan seterusnya ke bawah hingga level terakhir dari alternatif (Saaty, 1993). Pengolahan data AHP dilakukan dengan menggunakan program Expert Choice Versi 11.

\section{HASIL DAN PEMBAHASAN}

\section{ANALISIS GRAND STRATEGY}

Perumusan strategi dengan menggunakan AHP dimulai dengan mengidentifikasi faktor internal dan eksternal. Identifikasi ini dilakukan untuk menentukan faktor-faktor apa saja yang menjadi kekuatan dan kelemahan, serta peluang dan ancaman yang ada di Kabupaten Sleman dalam upaya pengembangan agribisnis cabai merah. Faktor internal (kekuatan dan kelemahan) dan eksternal (peluang dan ancaman) dapat menggambarkan kondisi yang ada di Kabupaten Sleman, sehingga memudahkan dalam merumuskan strategi yang akan dimasukkan ke dalam struktur hirarki AHP.

Setelah faktor-faktor internal (kekuatan dan kelemahan) dan eksternal (peluang dan ancaman) diketahui selanjutnya dibuat dalam bentuk matrik IFE dan EFE untuk melihat bobot prioritas dari masingmasing faktor.
TABEL 4. FAKTOR INTERNAL DAN EKSTERNAL

\begin{tabular}{ll}
\hline Faktor Internal dan Eksternal \\
\hline Kekuatan (Strenghts) \\
\hline 1 & Ketersediaan sarana produksi \\
2 & Kualitas cabai merah bagus \\
3 & Hasil produksi ada setiap hari \\
4 & Peniualan hasil produksi melalui pasar lelang \\
5 & Akses modal mudah dijangkau \\
\hline Kelemahan (Weakness) \\
\hline 1 & Pengawasan terhadap bibit yang digunakan masih lemah \\
2 & Kemampuan petani dalam penerapan teknologi masih kurang \\
3 & Belum ada pengolahan lebih lanjut dari hasil produksi \\
4 & Masih ada kelembagaan petani yang kurang aktif \\
5 & Fasilitas pasar lelang masih kurang \\
\hline Peluang (Opportunity) \\
\hline 1 & Permintaan pasar terhadap cabai merah tinggi \\
2 & Iklim dan tanah yang cocok untuk budidaya cabai merah \\
3 & Adanya teknologi yang membantu dalam budidaya \\
4 & Pengolahan cabai merah menjadi produk lain \\
5 & Terbukanya lembaga keuangan bagi petani untuk memperoleh modal \\
\hline Ancaman (Threats) \\
\hline 1 & Serangan OPT \\
2 & Persaingan dengan daerah lainnya \\
3 & Belum ada jaminan harga \\
4 & Harga cabai merah sering berlluktuasi \\
5 & Cuaca yang tidak menentu \\
\hline Sumber : Data Primer \\
\end{tabular}

Hasil pembobotan dapat dilihat pada tabel 5 dan tabel 6.

TABEL 5. MATRIK IFE

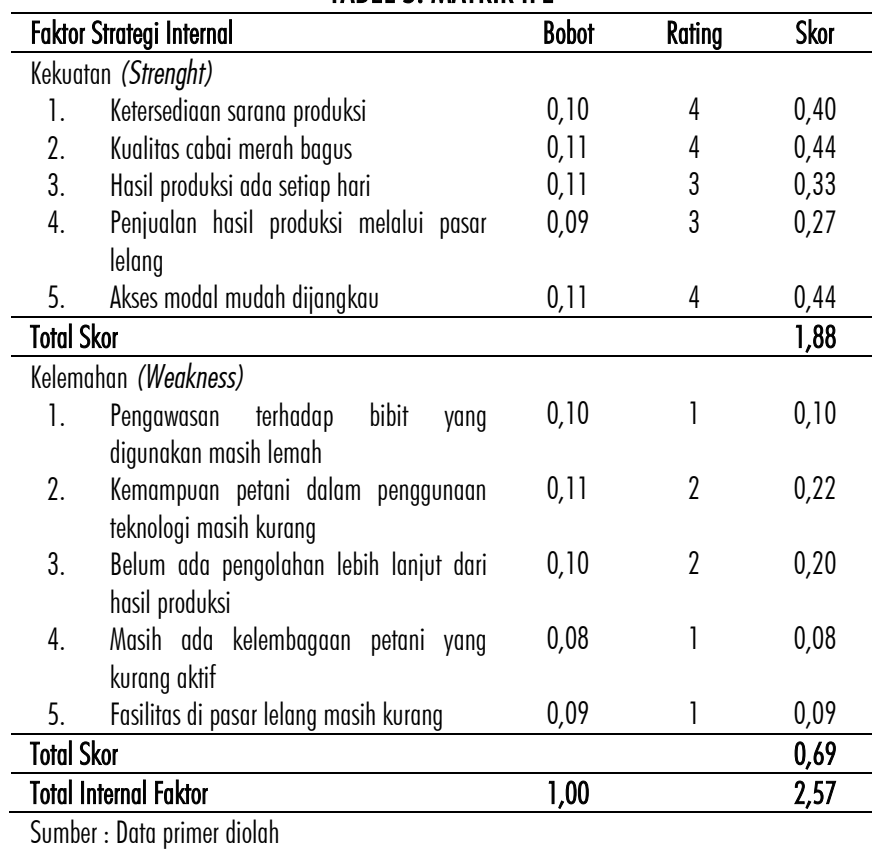

Berdasarkan hasil matrik IFE pada faktor kekuatan, kualitas cabai merah yang bagus dan akses modal yang mudah dijangkaun memiliki skor tertinggi dengan nilai 0,44. Kualitas cabai merah dari 
Kabupaten Sleman memiliki keunggulan dibandingkan dengan cabai merah dari daerah lainnya di Provinsi Yogyakarta. Menurut hasil wawancara dengan responden, keunggulan itu terletak pada daya tahan cabai dan warna merah yang baik, sehingga cabai merah tersebut banyak peminatnya hingga sampai ke luar jawa. Untuk skor yang terendah adalah penjualan hasil produksi melalui pasar lelang dengan nilai skor 0,27. Sementara itu pada faktor kelemahan, kemampuan petani dalam penggunaan teknologi masih kurang memiliki nilai skor tertinggi yaitu 0,22. Hal ini karena tingkat kemampuan SDM yang berbeda-beda dari petani dalam memahami dan mengaplikasikan teknologi dalam proses budidaya, sehingga penggunaan teknologi masih kurang baik. Faktor masih ada kelembagaan petani yang kurang aktif menjadi yang terendah dengan nilai skor 0,08.

TABEL 6. MATRIK EFE

\begin{tabular}{|c|c|c|c|}
\hline Foktor Strategi Eksternal & Bobot & Rating & Skor \\
\hline \multicolumn{4}{|l|}{ Peluang (Opportunity) } \\
\hline $\begin{array}{l}\text { 1. Permintaan pasar terhadap cabai merah } \\
\text { tinggi }\end{array}$ & 0,12 & 4 & 0,48 \\
\hline $\begin{array}{l}\text { 2. Iklim dan tanah yang cocok dalam } \\
\text { budidaya cabai merah }\end{array}$ & 0,09 & 3 & 0,27 \\
\hline $\begin{array}{l}\text { 3. Adanya teknologi yang membantu dalam } \\
\text { budidaya }\end{array}$ & 0,11 & 4 & 0,44 \\
\hline $\begin{array}{l}\text { 4. Pengolahan cabai merah menjadi produk } \\
\text { lain }\end{array}$ & 0,10 & 3 & 0,30 \\
\hline $\begin{array}{l}\text { 5. Terbukanya lembaga keuangan bagi } \\
\text { petani untuk memperoleh modal }\end{array}$ & 0,09 & 3 & 0,27 \\
\hline Total Skor & & & 1,76 \\
\hline \multicolumn{4}{|l|}{ Ancaman (Threats) } \\
\hline 1. Serangan OPT & 0,13 & 2 & 0,26 \\
\hline Persaingan dengan daerah lainnya & 0,09 & 2 & 0,18 \\
\hline Belum ada jaminan harga & 0,10 & 1 & 0,10 \\
\hline 4. Harga cabai merah sering berfluktuasi & 0,09 & 2 & 0,18 \\
\hline \multicolumn{4}{|l|}{ 5. Cuaca yang tidak menentu } \\
\hline & 0,08 & 2 & 0,16 \\
\hline Total Skor & & & 0,88 \\
\hline Total Eksternal Faktor & 1,00 & & 2,64 \\
\hline
\end{tabular}

Sumber : Data primer diolah

Berdasarkan hasil matrik EFE pada faktor peluang, permintaan pasar terhadap cabai merah tinggi memiliki skor tertinggi dengan nilai 0,48 . Menurut hasil wawancara dengan responden, cabai merah dari Kabupaten Sleman tidak hanya dijual di pasar lokal melainkan di kirim ke luar jawa. Untuk skor yang terendah adalah iklim dan tanah yang cocok dalam budidaya cabai merah dan terbukanya lembaga keuangan bagi petani untuk memperoleh modal dengan nilai skor 0,27. Sementara itu pada faktor ancaman, serangan OPT memiliki nilai skor tertinggi yaitu 0,26 dan belum ada jaminan harga menjadi yang terendah dengan nilai skor 0,10. Agribisnis cabai merah di Kabupaten Sleman memiliki kekuatan yang lebih besar daripada kelemahan dan memiliki peluang yang lebih besar daripada ancaman. Dalam hal ini, pemerintah daerah dan petani yang berperan dalam pengembangan agribisnis cabai merah memiliki peluang dan kekuatan yang lebih besar sehingga dapat memanfaatkan peluang yang ada secara maksimal.

Hasil perhitungan dari faktor internal dan eksternal digunakan untuk menentukan titik koordinat strategi pengembangan yang dapat dilakukan. Sumbu horizontal (X) adalah faktor internal, nilai dari koordinat $\mathrm{X}$ merupakan selisih faktor kekuatan dikurangi faktor kelemahan, yaitu $(1,88-0,69)=1,19$. Sedangkan sumbu vertikal $(Y)$ adalah faktor eksternal yang merupakan selisih faktor peluang dikurangi faktor ancaman, nilai dari koordinat $Y$ adalah $(1,76-0,88)=0,88$.

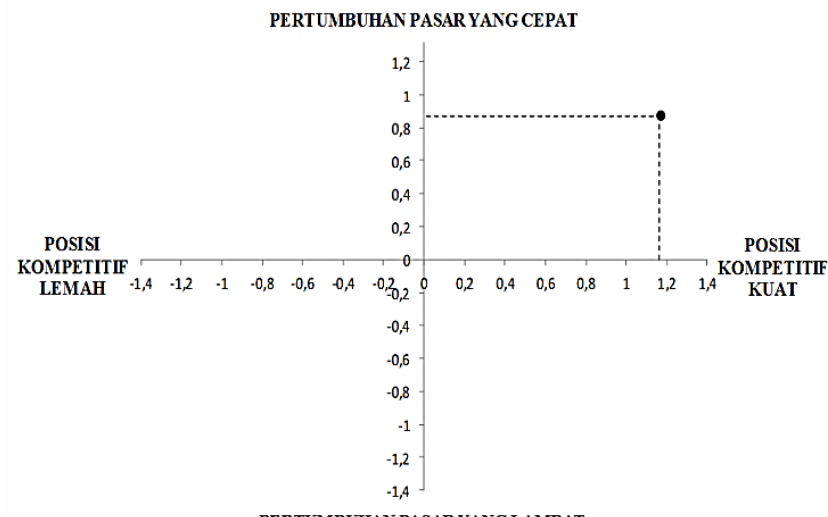

PERTUMBUUHAN PASARYANG LAMBAT

\section{GAMBAR 1. POSISI KUADRAN GRAND STRATEGY}

Hasil yang diperoleh dari matrik grand strategy (gambar 1) menunjukan posisi koordinat pada kuadran I (satu). Posisi ini mewakili organisasi atau perusahaan dengan pertumbuhan pasar yang tinggi dan posisi kompetitif yang kuat. Pada posisi seperti ini, agribisnis cabai merah di Kabupaten Sleman memiliki kekuatan yang lebih besar daripada kelemahan dan memiliki peluang yang lebih besar daripada ancaman. Pemerintah daerah bersama-sama dengan petani terus berkonsentrasi pada pasar saat ini 
dengan melaksanakan strategi yang sesuai, seperti pengembangan pasar dengan memperkenalkan hasil produksi cabai merah dari Kabupaten Sleman ke wilayah baru dengan memanfaatkan fungsi dari pasar lelang, agar bisa menjangkau pasar yang lebih luas.

\section{PENENTUAN ANALYTICAL HIERARCHY PROCESS (AHP)}

Analytical Hierarchy Process (AHP) merupakan alat analisis yang dapat digunakan untuk menilai satu alternatif pilihan dari beberapa pilihan alternatif yang tersedia (Hefnawi \& Mohamed, 2014). Struktur AHP dalam penelitian ini memiliki tujuan sebagai level pertama, kriteria pada level kedua dan alternatif pada level ketiga. Tujuan yang dimaksud yaitu menentukan strategi pengembangan agribisnis cabai merah di Kabupaten Sleman. Berdasarkan hasil wawancara didapat empat kriteria untuk pengembangan agribisnis cabai merah di Kabupaten Sleman dengan mengikuti Peraturan Menteri Pertanian Republik Indonesia No. 06/Permentan/ OT.140/2/2015 Tahun 2015, yaitu pengembangan agribisnis didasarkan pada aspek penyediaan sarana produksi, aspek produksi, aspek pemasaran dan pengolahan, serta aspek kelembagaan pendukung. Selanjutnya terdapat 5 alternatif strategi, yang diperoleh berdasarkan hasil identifikasi faktor internal dan faktor eksternal serta matrik grand strategy, yang ditentukan langsung oleh pakar.
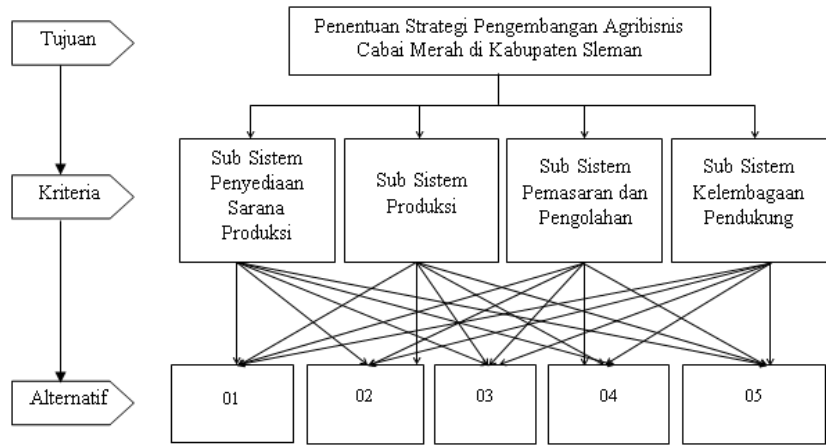

GAMBAR 1. HIRARKI AHP UNTUK PENENTUAN STRATEGI PENGEMBANGAN AGRIBISNIS CABAI MERAH DI KABUPATEN SLEMAN
TABEL 7. ALTERNATIF STRATEGI

\begin{tabular}{cl} 
Kode & \multicolumn{1}{c}{ Alternatif Strategi } \\
\hline 01 & Peningkatan pengawasan terhadap sarana produksi untuk budidaya cabai merah. \\
02 & Mengembangkan produksi melalui peningkatan kualitas, baik dari sarana produksi \\
03 & Man hasil produksi, serta kuantitas produksi cabai merah. \\
04 & Penambat industri pengolahan cabai merah. \\
05 & Pengembangan pasar lelang cabai dengan teknologi digital. \\
\hline Sumber : Data Primer
\end{tabular}

Hasil analisis AHP menunjukan kriteria yang menjadi prioritas dalam pengembangan agribisnis cabai merah adalah kriteria subsistem pemasaran dan pengolahan dengan nilai bobot prioritas sebesar 0,582 . Subsistem pemasaran dan pengolahan disebut juga sebagai subsistem agribisnis hilir, yaitu suatu sistem untuk memasarkan dan mengolah hasil komoditas pertanian, dalam hal ini cabai merah. Kriteria subsistem penyediaan sarana produksi memiliki nilai bobot terendah dalam rangka pengembangan agribisnis cabai merah di Kabupaten Sleman, yang ditunjukan dengan nilai bobot prioritas sebesar 0,075, karena sarana produksi mudah diperoleh oleh petani untuk melakukan budidaya cabai merah, baik dari pihak pengusaha atau toko pertanian yang ada di Kabupaten Sleman dan juga bantuan dari pemerintah daerah.

\section{TABEL 8. BOBOT KRITERIA AHP}

\begin{tabular}{clc}
\hline Peringkat & \multicolumn{1}{c}{ Kriteria } & Bobot AHP \\
\hline 1 & Subsistem Pemasaran dan Pengolahan & 0,582 \\
2 & Subsistem Produksi & 0,234 \\
3 & Subsistem Kelembagaan Pendukung & 0,109 \\
4 & Subsistem Penyediaan Sarana Produksi & 0,075 \\
\hline Sumber : Analisis data primer
\end{tabular}

Sistem pemasaran yang sedang dikembangkan oleh pemerintah daerah Kabupaten Sleman adalah melalui sistem penjualan cabai satu pintu di pasar lelang. Hal ini dilakukan untuk memutus rantai penjualan yang panjang sehingga petani dapat memperoleh harga yang jauh lebih baik dari pedagang besar.

Saat ini terdapat 10 titik kumpul pasar lelang untuk menampung hasil panen cabai dari petani di Kabupaten Sleman. Aspek pemasaran sebagai aspek penting bagi petani untuk dapat menjual hasil produksinya secara berkesinambungan. Terpilihnya aspek pasar mencerminkan kinerja produksi agribisnis 
cabai merah yang sangat erat kaitannya dengan masalah pasar (Oelviani, 2013).

Penentuan alternatif strategi dilihat dari kriteria subsistem penyediaan sarana produksi menunjukan bahwa hasil alternatif strategi 02 memiliki nilai tertinggi dengan nilai bobot prioritas sebesar 0,323. Hal ini berarti peningkatan kualitas terhadap sarana produksi sangat penting dilakukan dalam rangka mengembangkan agribisnis cabai merah. Untuk meningkatkan produksi dan kualitas tanaman cabai digunakan varietas yang unggul dan pupuk (Syahputra, Astuti \& Indrawaty, 2017). Peningkatan kualitas sarana produksi harus diikuti dengan pengawasan yang baik. Fungsi pengawasan menekankan pada bagaimana membangun sistem pengawasan dan melaksanakan pengawasan terhadap rencana yang telah dibuat agar tetap berjalan pada rel yang telah ditetapkan (Said \& Intan, 2001). Alternatif strategi yang memiliki nilai terendah adalah strategi 04 dengan nilai bobot prioritas sebesar 0,059, yaitu penambahan titik kumpul pasar lelang cabai.

Hasil alternatif strategi dilihat dari kriteria subsistem produksi (budidaya) atau disebut juga sebagai subsistem usahatani menunjukan alternatif strategi 02 dengan nilai bobot prioritas tertinggi, yaitu sebesar 0,429. Strategi 02 yaitu mengembangkan produksi melalui peningkatan kualitas, baik dari sarana produksi dan hasil produksi, serta kuantitas produksi cabai merah.

TABEL 9. BOBOT ALTERNATIF STRATEGI BERDASARKAN SUBSISTEM PENYEDIAAN SARANA PRODUKSI

\begin{tabular}{ccc}
\hline Peringkat & Alternatif Strategi & Bobot AHP \\
\hline 1 & 02 & 0,323 \\
2 & 01 & 0,312 \\
3 & 05 & 0,178 \\
4 & 03 & 0,127 \\
5 & 04 & 0,059 \\
\hline \multicolumn{2}{c}{ Sumber : Analisis data primer }
\end{tabular}

Menurut hasil wawancara dengan responden dari Dinas Pertanian, Pangan dan Perikanan Kabupaten Sleman, upaya peningkatan hasil produksi juga dilakukan dengan memberikan pembinaan kepada petani terhadap penanganan OPT. Hal ini menjadi perhatian khusus bagi pemerintah daerah terhadap petani dalam upaya mengidentifikasi serta menangani OPT secara baik dengan menerapkan sistem Pengendalian Hama Terpadu (PHT), guna meningkatkan kualitas dan kuantitas produksi. Pengendalian Hama Terpadu (PHT) berdampak positif terhadap ekonomi petani karena mampu mengurangi penggunaan pestisida serta meningkatkan pengetahuan dan keterampilan petani secara tidak langsung (Irham \& Mariyono, 2001). Alternatif strategi yang memiliki nilai terendah adalah strategi 04 dengan nilai bobot prioritas 0,072 .

\begin{tabular}{ccc} 
TABEL 10. BOBOT ALTERNATIF STRATEGI BERDASARKAN SUBSISTEM & PRODUKSI \\
\hline \multicolumn{3}{c}{ PAlernotif Strategi } \\
\hline Peringkot & 02 & Bobot AHP \\
\hline 1 & 05 & 0,429 \\
2 & 01 & 0,197 \\
3 & 03 & 0,172 \\
4 & 04 & 0,130 \\
5 & & 0,072 \\
\hline
\end{tabular}

Sumber : Analisis data primer

Alternatif strategi dilihat dari kriteria subsistem pemasaran dan pengolahan atau disebut juga sebagai subsistem hilir menunjukan bahwa alternatif strategi 05 memiliki nilai tertinggi dengan nilai bobot prioritas sebesar 0,439. Strategi 05 adalah pengembangan pasar lelang cabai dengan teknologi digital. Dalam hal ini pengembangan agribisnis cabai merah di Kabupaten Sleman berbasis teknologi digital harus dilakukan. Hal ini senada dengan penelitian Purwandani, Rahayu \& Setyowati (2016) di Kabupaten Kulon Progo, yang menyatakan bahwa pengembangan Pasar Lelang Gisik Pranaji di Kecamatan Panjatan dapat dilakukan dengan perluasan pasar dengan memanfaatkan media online (internet) atau teknologi informasi untuk menarik pedagang Alternantif strategi yang memiliki nilai terendah adalah strategi 01 dengan nilai bobot prioritas 0,059 .

TABEL 11. BOBOT ALTERNATIF STRATEGI BERDASARKAN SUBSISTEM PEMASARAN DAN PENGOLAHAN

\begin{tabular}{ccc}
\hline Peringkat & Alternatif Strategi & Bobot AHP \\
\hline 1 & 05 & 0,439 \\
2 & 04 & 0,216 \\
3 & 03 & 0,181 \\
4 & 02 & 0,105 \\
5 & 01 & 0,059 \\
\hline
\end{tabular}

Sumber : Analisis data primer

Alternatif strategi dilihat dari kriteria subsistem kelembagaan pendukung menunjukan 
bahwa alternatif strategi 05 memiliki nilai tertinggi dengan nilai bobot prioritas sebesar 0,434. Pengembangan pasar lelang cabai dengan teknologi digital dapat dilakukan dengan melibatkan lembaga pendukung yang berkaitan dengan pemasaran. Dalam hal ini pemerintah daerah bersama dengan kelompok tani dapat membangun ataupun meningkatkan hubungan kerja sama (mitra) melalui teknologi informasi dengan lembaga-lembaga yang dapat menunjang pengembangan pasar cabai merah dari Kabupaten Sleman, seperti koperasi, pasar tradisional, pasar induk, pasar swalayan dan juga perusahaan industri pengolahan cabai merah. Upaya membentuk pola kemitraan agribisnis hortikultura dapat dilakukan dengan cara membentuk atau memperkuat kelompok tani atau asosiasi petani. Untuk menggerakan dan memajukan agribisnis semua lembaga harus berperan secara aktif sinergis dan saling terkoordinasi agar tidak terjadi tumpang tindih kepentingan dan efisiensi dapat dicapai (Wahyuningsih, 2007). Ada beberapa alternatif pemecahan masalah bagi petani, terutama untuk masalah kurangnya permodalan petani. Alternatif tersebut adalah melalui kemitraan dengan lembaga keuangan formal atau bermitra dengan lembaga keuangan non formal (Yulianjaya \& Hidayat, 2016). Kelembagaan berdasarkan private sector dapat melibatkan peran dari industri pengolahan sebagai tujuan pemasaran hasil panen dengan kontrak kerja sama yang telah disepakati dan melibatkan pasar sebagai tujuan utama (Tsurayya \& Kartika, 2015). Alternatif strategi yang memiliki nilai terendah adalah strategi 01 dengan nilai bobot prioritas 0,068 .

TABEL 12. BOBOT ALTERNATIF STRATEGI BERDASARKAN SUBSISTEM KELEMBAGAAN PENDUKUNG

\begin{tabular}{ccc}
\hline Peringkat & Alternatif Strotegi & Bobot AHP \\
\hline 1 & 05 & 0,434 \\
2 & 03 & 0,192 \\
3 & 02 & 0,173 \\
4 & 04 & 0,133 \\
5 & 01 & 0,068 \\
\hline
\end{tabular}

Sumber : Analisis data primer

Hasil penilaian (tabel 13) dari AHP menunjukan bahwa urutan prioritas alternatif strategi pengembangan agribisnis cabai merah di Kabupaten Sleman adalah strategi 05 dengan nilai bobot prioritas 0,357 , strategi 02 dengan nilai bobot prioritas 0,209 , strategi 03 dengan nilai bobot prioritas 0,165 dan strategi lainnya yang berada di posisi bawah. Strategi 05 adalah pengembangan pasar lelang cabai dengan teknologi digital. Cabai cepat sekali mengalami kerusakaan yang disebabkan oleh beberapa hal, seperti pembusukan oleh bakteri atau jamur yang menyebabkan cabai tersebut menyusut dan rusak, sehingga cabai harus segera dipasarkan dengan cepat untuk menghindari kerugian petani. Keberadaan pasar lelang menggantikan posisi petani untuk melakukan fungsi pemasaran seperti fungsi pertukaran, fungsi fisis serta fungsi penyediaan sarana pasar sehingga fungsi ini tidak perlu dilakukan sendiri (Rusdiyana, 2017). Apabila lembaga pasar lelang dikelola dengan baik maka dapat memberikan manfaat yang sangat tinggi bagi para petani cabai merah. Keberhasilan suatu pasar tidak semata-mata ditentukan oleh tersedianya barang dan pembeli, namun juga pengorganisasian lembaga dan pemasaran itu sendiri (Devi, Haryoso \& Subejo, 2015). Pasar lelang mampu menjamin terjualnya produk dengan harga yang menguntungkan bagi petani dan pedagang. Salah satu hal yang perlu dikembangkan dalam pasar lelang adalah perlunya informasi ketersediaan stok cabai dari petani sehingga dapat digunakan sebagai salah satu solusi untuk mengurangi fluktuasi harga cabai (Nugroho, Prasada, Putri, Anggarasari \& Sari, 2018).

Memperluas jaringan pemasaran dan distribusi adalah bagian dari pengembangan pasar Oleh sebab itu di era teknologi seperti ini, pengembangan pasar dilakukan dengan berbasis teknologi, yaitu teknologi informasi dan digital. Penelitian Lestari, Widyayanthi \& Kuntadi (2014), menjelaskan strategi pengembangan usahatani cabai merah besar di Jember dapat dilakukan dengan memperluas jangkauan pemasaran. Bentuk strategi ini merupakan strategi untuk meraih pangsa pasar yang lebih luas. Melihat potensi cabai merah besar dengan permintaan pasar yang tinggi memperluas pemasaran merupakan strategi yang tepat, karena mampu mempengaruhi perkembangan usahatani cabai merah besar. 
TABEL 13. BOBOT ATAS SELURUH ALTERNATIF

\begin{tabular}{ccc}
\hline Peringkat & Alternatif Strategi & Bobot AHP \\
\hline 1 & 05 & 0,357 \\
2 & 02 & 0,209 \\
3 & 03 & 0,165 \\
4 & 04 & 0,158 \\
5 & 01 & 0,111 \\
\hline
\end{tabular}

Sumber : Analisis data primer

Berdasarkan hasil wawancara dengan responden dari Dinas Pertanian, Pangan dan Perikanan, serta pengurus pasar lelang Kabupaten Sleman, saat ini pemerintah daerah sedang dalam proses melakukan kerja sama dengan Kementrian Informasi dan Komunikasi dalam pembuatan portal atau website pasar lelang Sleman. Website ini nantinya dapat diakses di seluruh wilayah Indonesia dan memberikan informasi mengenai hasil produksi cabai merah dan juga informasi harga yang berlaku.

Jika dilihat dari tabel 13, alternatif strategi 01 memiliki nilai bobot terendah yaitu 0,111. Alternatif strategi 01 adalah peningkatan pengawasan terhadap sarana produksi untuk budidaya cabai merah. Menurut hasil wawancara, bahwa saat ini pemerintah daerah melalui Dinas Pertanian, Pangan dan Perikanan Kabupaten Sleman sudah melakukan pengawasan terhadap penggunaan sarana produksi kepada petani, namun dalam hal ini pengawasan belum berjalan dengan maksimal karena jumlah pekerja di bagian pengawasan yang terbatas. Untuk itu, melalui program-program yang diberikan kepada kelompok tani diharapkan dapat memaksimalkan penyampaian informasi langsung kepada petani mengenai penggunaan sarana produksi yang berkualitas.

\section{KESIMPULAN}

Berdasarkan hasil analisis internal dan eksternal diperoleh 5 alternatif strategi yang dimasukkan dalam hirarki AHP. Alternatif strategi tersebut sebagai pilihan-pilihan dalam rangka pengembangan agribisnis cabai merah di Kabupaten Sleman. Dari 5 alternatif strategi yang ada, maka terpilih alternatif strategi 05 dengan nilai bobot prioritas 0,357 yaitu pengembangan pasar lelang cabai dengan teknologi digital. Pemerintah daerah melalui dinas terkait bersama-sama dengan petani dapat membangun kerja sama atau meningkatkan hubungan kemitraan yang sudah terbentuk, untuk mengembangkan pasar lelang cabai dengan menggunakan teknologi digital. Pengembangan agribisnis cabai merah dengan pendekatan teknologi digital harus disertai dengan ketersediaan SDM yang berkualitas serta memahami aspek-aspek pemasaran. Sehingga sistem pemasaran hasil produksi cabai dapat diakses di seluruh wilayah Indonesia.

\section{DAFTAR PUSTAKA}

Antriyandarti, E., \& Ani, S.W. (2015). Pengembangan Agribisnis Cabai Merah (Capsicum annuum L) Di Kabupaten Magelang. Media Trend: Journal Of Economic \& Development Studies, 10 (1). http://dx.doi.org/10.21107/mediatren d.v10i1.668

BPS. (2018). Sleman Dalam Angka 2018. Kabupaten Sleman. Retrieved from http://slemankab.bps .go.id

David, F.R. (2011). Strategic Management : Manajemen Strategi Konsep. Jakarta: Salemba Empat.

Devi, P., Haryoso, \& Subejo. (2015). Keefektifan Lembaga Pasar Lelang Cabai Merah Di Kecamatan Panjatan, Kabupaten Kulon Progo. Jurnal Agro Ekonomi, 26 (2) https://doi.org/10.22146/agroekonomi.1727 3

Direktorat Jenderal Prasarana dan Sarana Pertanian. (2015). Pedoman Pengembagan Usaha Agribisnis Perdesaan TA 2015. Jakarta. Retrieved from http://psp.pertanian.go.id

Hefnawi, A., \& Mohamed, A.S. (2014). Review of Different Methods for Deriving Weights Hierarchy Process. International Journal of the Analytical Hierarchy Process, 6 (1) http://dx.doi.org./10.13033/ijahp.vGil-226

Irham \& Mariyono, J. (2001). Perubahan Cara Pengambilan Keputusan Oleh Petani Pengendalian Hama Terpadu (PHT) dalam Menggunakan Pestisida Kimia pada Padi. Jurnal Manusia dan Lingkungan, 8 (2). 91 97. http://doi.org/10.22146/ jml.18576

Lestari, D.P., Widyayanthi, L., \& Kuntadi, E.B. (2014). Tingkat Motivasi dan Strategi Pengembangan Usahatani Cabai Merah Besar di Jember. Agritrop Jurnal Ilmu-ilmu Pertanian, 12 (2) http://dx.doi.org/10.32528/agr.v12i2.721

Moleong, L.J. (2007). Metodologi Penelitian Kualitatif. Bandung: Remaja Rosdakarya.

Nazir, M. (2009). Metode Penelitian. Bogor: Ghalia Indonesia. 
Nugroho, A.D., Prasada I.M.Y., Putri, S.K., Anggarasari, H., \& Sari, P.N. (2018). Rantai Nilai Cabai di Lahan Pasir Pantai Kabupaten Kulon Progo. Economics Development Analysis Journal, 7 (4).https://doi.org/10.15294/edaj.v7i4.25013

Oelviani, R. (2013). Penerapan Metode Analytical Hierarchy Process Untuk Merumuskan Strategi Penguatan Kinerja Sistem Agribisnis Cabai Merah Di Kabupaten Temanggung. Informatika Pertanian, 22 (1). http://dx.doi. org/10.21082/ip. v22n1.2013.p11-19

Purwandani, K.M., Rahayu, W., \& Setyowati, N. (2016). Strategi Pengembangan Pasar Lelang Cabai Merah Lahan Pasir Di Kawasan Pesisir Kecamatan Panjatan, Kabupaten Kulon Progo. Jurnal Agrista, 4 (3). https://jurnal. uns.ac.id/agrista/ article/view/30776/20536

Rusdiyana, E. (2017). Peran Pasar Lelang Dalam Pemasaran Cabai Di Kelompok Tani Lahan Pasir Pantai Kulon Progo, Yogyakarta. Jurnal Caraka Tani, 32 (1). https://doi.org/10.20961 /carakatani.v32i1.14666

Saaty, T.L. (1993). Pengambilan Keputusan Bagi Para Pemimpin, Proses Hirarki Analitik untuk Pengambilan Keputusan dalam Situasi yang Kompleks. Pustaka Binama Pressindo.

Said, E.G., \& Intan, A.H. (2001). Manajemen Agribisnis. Jakarta: Ghalia Indonesia.

Saragih, B. (2001). Suara Dari Bogor: Membangun Sistem Agribisnis. Bogor : Yayasan USESE \& Sucofindo.

Sugiyono. (2014). Metode Penelitian Kuantitatif, Kualitatif dan R\&D. Bandung: Alfabeta.

Syahputra, E., Astuti, R., \& Indrawaty, A. (2017). Kajian Agronomis Tanaman Cabai Merah (Capsicum annum L) Pada Berbagai Jenis Bahan Kompos. Jurnal Agroteknologi dan IImu Pertanian, 1 (2). http://ojs.uma.ac.id/index.ph p/ agrotekma/article/view/1127

Tsurayya, S., \& Kartika, L. (2015). Kelembagaan Dan Strategi Peningkatan Daya Saing Komoditas Cabai Kabupaten Garut. Jurnal Manajemen \& Agribisnis, 12 (1). https://jurnal.ipb.ac.id/ind ex.php/jmagr/article/view/10061

Wahyuningsih, S. (2007). Pengembangan Agribisnis Ditinjau Dari Kelembagaan. Mediaagro, 3 (1). https://publikasiilmiah.unwahas.ac.id/index.p hp/Mediagro /article/view/537/659

Yulianjaya, F., \& Hidayat, K. (2016). Pola Kemitraan Petani Cabai Dengan Juragan Luar Desa (Studi Kasus Kemitraan di Desa Kucur, Kecamatan Dau, Kabupaten Malang). Jurnal Habitat, 27 (1). https://doi.org/10.21776/ub. habitat.2016. 027.1.5 